\title{
Issues of long-term durability of paper - Labest Papier
}

\author{
Heinz Joachim Schaffrath \\ Fachgebiet Papierfabrikation und Mechanische Verfahrenstechnik (PMV), Technische Universität Darmstadt, \\ Alexanderstr. 8, 64283 Darmstadt, Germany
}

Correspondence: Heinz Joachim Schaffrath (heinz-joachim.schaffrath@tu-darmstadt.de)

Published: 10 November 2021

\begin{abstract}
In the project "Labest Papier - Langzeitbeständigkeit von Papier" (Labest Paper - Long-term durability of paper), the suitability of paper to serve as a permanently undamaged information carrier for at least 500 years is to be assessed by the Department of Paper Manufacturing and Mechanical Process Engineering (PMV) for the Federal Office for the Safety of Nuclear Waste Disposal (BASE).

The ageing mechanisms of paper are known, as are countermeasures. This leads to standards and recommendations for the use of paper for documents. DIN EN ISO 9706 (2010) is the main proponent of the direction that longevity can be ensured solely via the composition of the paper and the initial situation at the beginning of ageing. DIN 6738 (2007), on the other hand, takes as its basis the approach of assessing the physical ageing of the paper based on artificial ageing and the strength losses observed in the process. Other standards vary the approaches somewhat or mix them in part, for which the lecture presents a comparison table.

The usability of a document depends on two essential factors. Firstly, the residual strength after an ageing process must be high enough for the document to be usable. Secondly, the information written on it must still be legible or at least recognisable.

The limits of the possibilities for dealing with damage that has already occurred are almost only set by complete destruction. Otherwise, forensic means can restore the information in a document, at least in part, with the appropriate investment of time and money. The lecture provides examples, such as the reprocessing of shredded Stasi files. Even the loss of knowledge of writing and language need not be a final obstacle, as the decipherment of hieroglyphics proves. The costs of measures to deal with damage depend individually on the condition of the documents and on the objectives in dealing with the damage. Prevention is an effective means of avoiding damage and costs in the first place.

Paper is an information carrier well known for over 2000 years and has already proven its suitability for storing long-term information. Despite the fact that an intactness in the sense of being completely untouched is never given, paper has the advantage of a long migration time and that no reading or decoding device is necessary compared to modern information storage media, such as digital media or microfilm. Which grade of paper will ultimately meet the demands, however, depends on the overall consideration of the availability of the grade, the expected damage and the possibilities and costs of handling it.

There is still a need for research, especially with respect to the assessment of the effect of printing inks and auxiliaries used in paper production on the longevity as well as the classification of recycled paper. An extensive measurement program is investigating this during the current project. After the project is accomplished, BASE will be able to decide in which way the already existing types of papers including marking can be preserved for as long as necessary and how the state-of-the-art optimised system "paper ink" must be prepared to ensure longterm durability. The paper is based on two working stage reports, AP1 (Schaffrath, 2020) and AP2 (Schaffrath,
\end{abstract} 2021).

Kurzfassung. Im Projekt „Labest Papier - Langzeitbeständigkeit von Papier“ soll vom Fachgebiet Papierfabrikation und Mechanische Verfahrenstechnik (PMV) der TU Darmstadt im Auftrag des Bundesamts für die Sicherheit der nuklearen Entsorgung (BASE) die Eignung von Papier untersucht werden, als permanent unbeschädigter Informationsträger für mindestens 500 Jahre zu dienen. 
Die Alterungsmechanismen von Papier sind bekannt, ebenso wie die Gegenmaßnahmen. Das führt dazu, dass es Standards und Empfehlungen für den Gebrauch von Papier für Dokumente gibt. Die DIN EN ISO 9706 (2010) ist der Hauptbefürworter der Richtung, dass Langlebigkeit allein durch die Zusammensetzung des Papiers und die initiale Situation zu Beginn der Alterung sichergestellt werden kann. Dagegen besteht die Grundlage bei der DIN 6738 (2007) in dem Ansatz, dass die Beurteilung der physischen Alterung des Papiers auf der Basis artifizieller Alterung und des während dieses Prozesses beobachteten Festigkeitsverlusts erfolgt. In anderen Standards werden die Ansätze in gewisser Weise variiert oder teilweise vermischt, dazu wird im Vortrag eine Vergleichstabelle präsentiert.

Die Verwendbarkeit eines Dokuments hängt von 2 wesentlichen Faktoren ab. Erstens muss die verbliebene Festigkeit nach einem Alterungsprozess hoch genug dafür sein, dass das Dokument verwendet werden kann. Zweitens müssen die darauf geschriebenen Informationen noch lesbar oder wenigstens erkennbar sein.

Die Grenzen der Möglichkeiten zur Behebung von bereits eingetretenen Schäden werden fast nur durch die vollständige Zerstörung gesetzt. Ansonsten lassen sich die Informationen in einem Dokument, wenigstens zum Teil, durch forensische Mittel mit dem entsprechenden Einsatz von Zeit und Geld wiederherstellen. Im Vortrag werden Beispiele gegeben wie die Rekonstruktion geschredderter Stasi-Akten. Selbst der Verlust der Kenntnisse über Schrift und Sprache muss kein endgültiges Hindernis darstellen, wie die Entzifferung von Hieroglyphen zeigt. Die Kosten der Maßnahmen, um den Schaden zu beheben, hängen von dem Zustand der Dokumente im Einzelfall und den Zielen bei der Handhabung des Schadens ab. Überhaupt ist Prävention ein wirksames Mittel zur Schadens- und Kostenvermeidung.

Papier ist seit über 2000 Jahren als Informationsträger bekannt und hat seine Eignung für die Langzeitspeicherung von Informationen bereits erwiesen. Trotz der Tatsache, dass eine Unversehrtheit im Sinne des vollständigen Unberührtseins nie gegeben ist, hat Papier den Vorteil einer langen Migrationszeit und dass kein Lese- oder Decodiergerät notwendig ist - im Vergleich zu modernen Informationsspeichermedien wie digitalen Medien oder Mikrofilm. Welche Papierqualität jedoch letztlich den Anforderungen entspricht, hängt von der Gesamtbetrachtung der Verfügbarkeit der Papierqualität, des zu erwartenden Schadens und der Möglichkeiten und Kosten der Handhabung des Schadens ab.

Weitere Forschung ist noch erforderlich, insbesondere im Hinblick auf die Untersuchung der Auswirkungen von Druckertinten und Hilfsstoffen, die in der Papierherstellung eingesetzt werden, auf die Langlebigkeit sowie die Klassifikation von Recycling-Papier. Im Rahmen eines ausgedehnten Maßnahmenprogramms werden diese Aspekte das während des laufenden Projekts untersucht. Nach Beendigung des Projekts wird das BASE in der Lage sein zu entscheiden, auf welche Weise die bereits vorhandenen Arten von Papieren einschließlich Beschriftung so lang wie sicherheitsrelevant notwendig erhalten werden können und wie das nach Stand der Wissenschaft und Technik optimierte System „Papier - Tinte“ zur Gewährleistung langfristiger Haltbarkeit präpariert werden muss. Der Artikel basiert auf zwei Arbeitsstandberichten, AP1 (Schaffrath, 2020) and AP2 (Schaffrath, 2021).

\section{References}

DIN 6738: Papier und Karton - Lebensdauerklassen, Beuth-Verlag GmbH, Berlin, Germany, 2007.

DIN EN ISO 9706: Information and documentation - Paper for documents - Requirements for permanence, Beuth-Verlag GmbH, Berlin, Germany, 2010.
Schaffrath, H. J.: Projekt „Labest Papier“: Arbeitsstandbericht AP1: Literaturrecherche, TU Darmstadt, Darmstadt, Germany, 2020.

Schaffrath, H. J.: Projekt „Labest Papier“: Arbeitsstandbericht AP2: Handhabung typischer Schäden, TU Darmstadt, Darmstadt, Germany, 2021. 